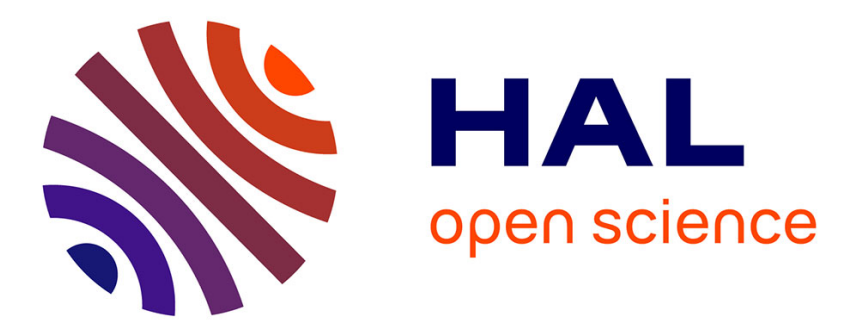

\title{
Isolation of green coffee chlorogenic acids using activated carbon
}

\author{
Mirna Leonor Suarez-Quiroz, Angelina Alonso Campos, Gerardo Valerio \\ Alfaro, Oscar Gonzalez-Rios, Pierre Villeneuve, Maria Cruz Figueroa-Espinoza
}

\section{To cite this version:}

Mirna Leonor Suarez-Quiroz, Angelina Alonso Campos, Gerardo Valerio Alfaro, Oscar Gonzalez-Rios, Pierre Villeneuve, et al.. Isolation of green coffee chlorogenic acids using activated carbon. Journal of Food Composition and Analysis, 2014, 33 (1), pp.55-58. 10.1016/j.jfca.2013.10.005 . hal-01223544

\section{HAL Id: hal-01223544 \\ https://hal.science/hal-01223544}

Submitted on 2 Nov 2015

HAL is a multi-disciplinary open access archive for the deposit and dissemination of scientific research documents, whether they are published or not. The documents may come from teaching and research institutions in France or abroad, or from public or private research centers.
L'archive ouverte pluridisciplinaire HAL, est destinée au dépôt et à la diffusion de documents scientifiques de niveau recherche, publiés ou non, émanant des établissements d'enseignement et de recherche français ou étrangers, des laboratoires publics ou privés. 


\title{
Short Communication
}

\section{Isolation of green coffee chlorogenic acids using activated carbon}

\author{
Mirna Leonor Suárez-Quiroz ${ }^{a}$, Angelina Alonso Campos ${ }^{a}$, Gerardo Valerio Alfaro ${ }^{a}$, \\ Oscar González-Ríos a , Pierre Villeneuve ${ }^{\mathrm{b}}$, Maria Cruz Figueroa-Espinoza ${ }^{\mathrm{c}, *}$ \\ ${ }^{a}$ Instituto Tecnológico de Veracruz, Unidad de Investigación y Desarrollo en Alimentos, Miguel Angel de Quevedo N 2779,91860 Veracruz, Veracruz, Mexico \\ ${ }^{\mathrm{b}}$ CIRAD, UMR 1208 IATE, 2 Place Viala, F-34060 Montpellier, France \\ ${ }^{\mathrm{c}}$ Montpellier SupAgro, UMR 1208 IATE, 2 Place Viala, F-34060 Montpellier, France
}

\section{A R T I C L E I N F O}

\section{Article history:}

Received 1 November 2012

Received in revised form 20 September 2013

Accepted 5 October 2013

\section{Keywords:}

Activated carbon

Chlorogenic acids

Green coffee

Extraction

5-O-Caffeoylquinic acid

Isolation

Environmentally friendly

Food analysis

Food composition

\begin{abstract}
A B S T R A C T
Chlorogenic acids, which are interesting natural antioxidants widespread in the plant kingdom, were extracted and purified from Mexican green coffee beans (Coffea arabica) using different methods. The final objective was to find an easy way to extract high-value molecules from a complex mixture, avoiding as much as possible the use of toxic solvents. Three extraction methods (hot water at $80{ }^{\circ} \mathrm{C}$, aqueous methanol $70 \%(\mathrm{v} / \mathrm{v})$, and aqueous isopropanol $60 \%(\mathrm{v} / \mathrm{v}))$ were tested in combination with two isolating methods (activated carbon, different solvents). The extracted amounts of chlorogenic acids with the six treatments (4.67-5.87\% dry basis) presented no significant differences. The one using hot water for extraction and of activated carbon for isolation, was the simplest and the most environmentally friendly. Thus it can be used as a previous step to obtain from green coffee a mixture rich in chlorogenic acids which can be further fractionated to purify a specific chlorogenic acid (i.e. in this work, 5-O-caffeoyl quinic acid using a silica gel column). Chlorogenic acids can be used as natural antioxidants in food or non-food products. To the best of our knowledge, activated carbon has not been used to isolate chlorogenic acids from green coffee.
\end{abstract}

(c) 2013 Elsevier Inc. All rights reserved.

\section{Introduction}

Chlorogenic acids (CGA) (mono- and di-acyl quinic acids, with caffeic, ferulic, and $p$-coumaric acids as the main acylating residues) are natural antioxidants widespread in the plant kingdom (Clifford, 1999), and well represented in coffee beans. Depending on the species, green coffee beans contain some 6-10\% (dry basis (db)) of CGA, with levels of CGA higher in Coffea robusta beans than in C. arabica beans (Clifford, 1999; Debry, 1993; Ky et al., 1997). The most commonly found individual CGA is 5-Ocaffeoylquinic acid (5-CQA) (Fig. 1; IUPAC numbering (IUPAC, 1976)), often called chlorogenic acid, which is usually the only one commercially available. According to Clifford and Jarvis (1988), a Mexican robusta green coffee contained 5.98, 1.11, and $1.20 \%$ (db) of caffeoyl quinic acids (CQAs), feruloyl quinic acids (FQAs), and dicaffeoyl quinic acids (diCQAs), respectively. Ky et al. (1997) quantified CGA on a $C$. liberica var dewevrei, and they observed a maximum of $6.5 \%$ of 5- and 4-CQA from a total CQAs of $7.3 \%(\mathrm{db})$, and 0.76 and $1.43 \%(\mathrm{db})$ of total FQAs and diCQAs, respectively.

Different methods have been used to extract and isolate CGA from green coffee. Generally, beans are first frozen by liquid nitrogen to minimize CGA oxidation (Colonna, 1979) and ground.

\footnotetext{
* Corresponding author. Tel.: +33 04996128 42; fax: +33 0499613076 .

E-mail address: maria.figueroa@supagro.inra.fr (M.C. Figueroa-Espinoza).
}

Then most of the CGA extraction methods use polluting organic solvents as aqueous methanol (Andrade et al., 1997; Colonna, 1979; Dibert et al., 1989; Rakotomalala, 1992), aqueous methanol and Carrez reagents (Balyaya and Clifford, 1995; Clifford et al., 2003; Trugo and Macrae, 1984), or aqueous 2-propanol 70\% (v/v) (Morishita et al., 1984).

Adsorption can be a more environmental friendly technique allowing the separation of selected compounds from diluted solutions and avoiding the use of toxic solvents. It has been largely used for the recovery of plant phenolic compounds.

Activated carbons (AC) have been used as adsorbents to selectively separate phenolic compounds from foods or byproducts (Soto et al., 2011). Concerning the family of cinnamic acid derivatives, AC has been used to isolate ferulic acid from an aqueous sugar-beet pulp enzyme hydrolyzate (Couteau and Mathaly, 1997) and from the cooking water of maize (Creppy, 2002). To the best of our knowledge, AC has not been used to isolate CGA from green coffee beans. Reports on the use of other kind of absorbents to recover CGA can be found in literature, i.e. non polar resin tested on apple juice (Kammerer et al., 2007), hydrophobic styrene-divinylbenzene copolymer used on model solutions (Kubo et al., 2002) or on apple pomace (Schieber et al., 2003), and polyvinylpyrrolidone (Olsson and Samuelson, 1974).

The method proposed in this work could be an environmentally friendly procedure to extract value-added CGA compounds from coffee industry by-products (Murthy and Madhava Naidu, 2012), 


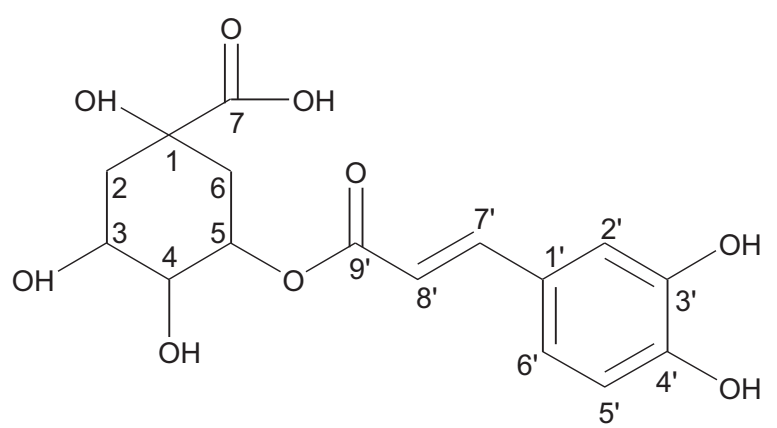

Fig. 1. Chemical structure of 5-O-caffeoyl quinic acid.

which are considered as waste materials and are widely available in the world. CGAs are phenolic compounds of interest as they present several biological and functional properties: antimicrobial, antiviral, anti-mycotoxigenic, anti-carcinogenic, antioxidant, chelating, and ultraviolet filter (Morishita and Ohnishi, 2001; Scholz et al., 1994; Suárez-Quiroz et al., 2004, 2013a, 2013b). CGAs could be then used as multifunctional natural antioxidants in food, feed, pharmaceutical, cosmetics or nutraceutical industries. In food and feed formulations, for example, these compounds could be used as natural antioxidant CGA-rich extracts with preservative properties.

The aim of this work was to compare six methods of extraction and isolation of CGA from green coffee beans, in order to find the simplest and the most environmentally friendly to be used as a previous step to simplify CGA fractionation. The example of 5-CQA purification from the CGA mixture is given. To our knowledge, this is the first report indicating the use of AC to isolate CGA from green coffee grains.

\section{Materials and methods}

\subsection{Plant material}

Green coffee beans (Coffea arabica) came from the Huatusco municipality (Veracruz, Mexico), and were harvested in 2008.

\subsection{Chemicals and materials}

5-CQA, acetic acid, ammonium sulphate, anhydrous sodium sulphate, butanol, ethanol $96 \%(\mathrm{v} / \mathrm{v})$, ethyl acetate, formic acid, iodine, isopropanol, methylene chloride, phosphoric acid, toluene, celite ( $\geq 95 \% \mathrm{SiO}_{2}$ basis), tetramethylsilane (TMS), and activated carbon (AC) (glassy spherical powder, 2-12 $\mu \mathrm{m}, 99.95 \%$ ) were purchased from Sigma Aldrich (Toluca, Mexico), and all solvents were of analytical grade; HPLC grade methanol from Baeyer (Mexico City, Mexico), aluminium thin layer chromatography (TLC) plates silica gel $60 \mathrm{~F}_{254}$ from Merck (Estado de México, Mexico).

\subsection{Sample preparation}

Green coffee beans were previously frozen by liquid nitrogen in order to minimize CGA degradation (Colonna, 1979), lyophilized, and ground with a coffee grinder (Krups North America, Inc., Mexico City, Mexico) to pass a $0.5 \mathrm{~mm}$ sieve.

\subsection{Extraction and isolation of CGA}

Three extraction and two isolation methods were tested in triplicate. Different extraction times for each method were tested (not shown) in order to obtain a maximum of CGA from green coffee. Only the most efficient time periods were retained for the rest of this work.

Extraction method 1. A mixture of lyophilized green coffee powder $(100 \mathrm{~g})$ and distilled water $(500 \mathrm{~mL})$ was magnetically stirred for $30 \mathrm{~min}$ at $80^{\circ} \mathrm{C}$, in the dark. After cooling, the solution was vacuum filtered through celite $(1 \mathrm{~cm})$.

Extraction method 2. A mixture of lyophilized green coffee powder $(100 \mathrm{~g})$ and aqueous methanol $70 \%(\mathrm{v} / \mathrm{v})(500 \mathrm{~mL})$ was magnetically stirred for $24 \mathrm{~h}$ at room temperature, in the dark. The solution was then vacuum filtered through celite $(1 \mathrm{~cm})$, and methanol was evaporated in a rotary evaporator (Bioblock, Mexico City, Mexico).

Extraction method 3. A mixture of lyophilized green coffee powder (100 g) and aqueous isopropanol $60 \%(\mathrm{v} / \mathrm{v})(500 \mathrm{~mL})$ was magnetically stirred for $48 \mathrm{~h}$ at room temperature, in the dark. The solution was then vacuum filtered through celite $(1 \mathrm{~cm})$, and isopropanol evaporated in a rotary evaporator.

Isolation method 1 (Rakotomalala, 1992). To aqueous extract obtained from each of the three extraction methods was added ammonium sulphate to a final concentration of $20 \mathrm{~g} / \mathrm{L}$, in order to precipitate proteins by increasing the ionic strength. To make CGA more soluble in ethyl acetate, $4 \%$ phosphoric acid was added. Extracts were then treated three times with methylene chloride $(300 \mathrm{~mL})$ to eliminate caffeine in the organic phase. The aqueous phase containing CGA was extracted 4 times using ethyl acetate $(300 \mathrm{~mL})$. The four ethyl acetate phases were pooled, dried with anhydrous sodium sulphate $(10 \mathrm{~g})$, filtered $\left(\mathrm{N}^{\circ} 1\right.$ filter paper, Whatman, Mexico City, Mexico), and dried at $40{ }^{\circ} \mathrm{C}$ and $120 \mathrm{rpm}$ in a rotary evaporator. The residue was analyzed by TLC and by HPLC.

Isolation method 2 (AC). The aqueous extract obtained from each of the three extraction methods was adjusted to $\mathrm{pH} 3.0$ with phosphoric acid, to which AC at $40 \mathrm{~g} / \mathrm{L}$ was added, and magnetically stirred for $30 \mathrm{~min}$ at $60{ }^{\circ} \mathrm{C}$, under dark. After cooling at room temperature, the mix was vacuum filtered through celite $(1 \mathrm{~cm})$. CGA were desorbed from AC using ethanol 96\% (v/v), then dried with anhydrous sodium sulphate, and finally dried in a rotary evaporator at $60{ }^{\circ} \mathrm{C}$ and $120 \mathrm{rpm}$. The residue was analyzed by TLC and by HPLC.

\subsection{Purification of 5-CQA}

The 5-CQA (Fig. 1) was purified from each of the six CGA mixtures with a silica gel 60 column $(25 \mathrm{~cm}$ long, $1.6 \mathrm{~cm}$ diameter $)$ using toluene/ethyl acetate $(90: 10, \mathrm{v} / \mathrm{v})$ as the eluted solvent. Collected fractions were dried in a rotary evaporator at $60{ }^{\circ} \mathrm{C}$ and $120 \mathrm{rpm}$, followed by a TLC, HPLC, and NMR analysis.

\subsection{Thin-layer chromatography (TLC)}

TLC was performed using aluminium silica gel $60 \mathrm{~F}_{254}$ plates $(4 \mathrm{~cm} \times 6.6 \mathrm{~cm})$. Five microliters of each sample or commercial 5CQA (used as the control) diluted in methanol, were spotted at $0.6 \mathrm{~cm}$ from the bottom of the plate. The TLC plate was then placed in a developing chamber containing butanol/water/acetic acid $(6: 2: 2, v / v / v)$ at room temperature (Lewis et al., 1998; Lu et al., 2004). When the solvent reached $0.4 \mathrm{~cm}$ from the top of the plate, the plate was removed, dried for $5 \mathrm{~s}$ with a hair-dryer, observed at 254 and $360 \mathrm{~nm}$, and finally revealed using iodine. The retention factor $\left(R_{\mathrm{f}}\right)$ was calculated as the distance travelled by the individual compound, divided by the distance travelled by the solvent. Assays were performed in duplicate.

\subsection{HPLC analysis}

Diluted samples were filtered (Millex-HV, Millipore Co.) $(0.45 \mu \mathrm{m})$ and injected $(10 \mu \mathrm{L})$ into an HPLC (Hypersil $C_{18}$; 
$5 \mu \mathrm{m} ; 250 \mathrm{~mm} \times 4.6 \mathrm{~mm}$; detection by UV absorbance at $276 \mathrm{~nm}$ and room temperature). Elution was performed during $14 \mathrm{~min}$ using aqueous methanol $\left(70 \%, \mathrm{v} / \mathrm{v}\right.$ ) at $1 \mathrm{~mL} / \mathrm{min}$, and $40{ }^{\circ} \mathrm{C}$ (Yuan et al., 2006). CGA are expressed as equivalents of 5-CQA. All samples were injected in triplicate.

\section{8. ${ }^{1} \mathrm{H} N M R$ and ${ }^{13} \mathrm{C} N M R$}

$30 \mathrm{mg}$ of the sample were analyzed by ${ }^{1} \mathrm{H}$ and ${ }^{13} \mathrm{C}$ NMR spectra were recorded using a Varian $500 \mathrm{MHz}$ NMR spectrometer in methanol- $\mathrm{D}_{4}$ solutions (Budryn et al., 2009; Hernandez et al., 2009). Chemical shifts were read relative to the internal standard (TMS).

\section{Results and discussion}

Methods using chemical reagents or organic solvents to extract and isolate phenolic compounds from plant extracts are not always ecologically friendly. In this research, AC was tested to isolate CGA from green arabica coffee beans as an alternative to limit the use of polluting solvents. Three extraction methods (water at $80^{\circ} \mathrm{C}$, aqueous methanol 70\% (v/v) and aqueous isopropanol 60\% (v/v)) and two isolation methods (Rakotomalala (1992) and AC) were tested. Results obtained from the six extraction-isolation treatments are presented in Table 1 . No significant differences $(\alpha=0.05)$ were observed between results and the CGA content varied from 4.67 to $5.87 \%(\mathrm{db})$.

$5-C Q A$ was then purified in a silica gel column from the CGA mixtures. The monitoring of 5-CQA purification (97\% of purity) was made by TLC $\left(R_{\mathrm{f}}=0.6\right)$ and HPLC, and its structure was confirmed by ${ }^{1} \mathrm{H}$ and ${ }^{13} \mathrm{C}$ NMR spectroscopy (Table 2). The purified 5-CQA was identified by comparison with spectroscopic data reported by Budryn et al. (2009), Hernandez et al. (2009), and Bhatt (2011).

The ${ }^{13} \mathrm{C}$ NMR spectrum showed the presence of sixteen carbon atoms, including two carbonyl groups at $\delta 175.61$ and $\delta 167.27$, corresponding to carbons 7 and $9^{\prime}$, respectively; two aromatic carbons bonded to hydroxyl groups at $\delta 148.11$ and $\delta 145.33$ identified as $\mathrm{C4}^{\prime}$ and $\mathrm{C}^{\prime}$; two olefinic carbons at $\delta 145.66$ and $\delta$ 113.79 corresponding to $\mathrm{C}^{\prime}$ and $\mathrm{C}^{\prime}$; four aromatic carbons assigned to $\mathrm{C}^{\prime}{ }^{\prime}, \mathrm{C2}^{\prime}, \mathrm{C}^{\prime}{ }^{\prime}$, and $\mathrm{C6}^{\prime}$ at $\delta 126.36, \delta 113.86, \delta 115.07$, and $\delta 121.58$, respectively; three carbons bonded to hydroxyl groups at $\delta 74.71, \delta 70.51$, and $\delta 72.06$ identified as $\mathrm{C} 1, \mathrm{C} 3$, and $\mathrm{C} 4$; one carbon bonded to an ester group at $\delta 70.57$ attributed to $\mathrm{C} 5$; and two methylene identified as $\mathrm{C} 2$ and $\mathrm{C} 6$ at $\delta 37.33$ and $\delta 36.76$, respectively.

The ${ }^{1} \mathrm{H}$ NMR spectrum displayed two ortho-coupled doublet each for $1 \mathrm{H}$, at $\delta 6.94$ and $\delta 6.75$, and a broad singlet for $1 \mathrm{H}$ at $\delta$ 7.027, confirming the presence of a tri-substituted aromatic ring; and two doublets, each for $1 \mathrm{H}$, at $\delta 7.56\left(\mathrm{H}-7^{\prime}\right)$ and $6.22\left(\mathrm{H}-8^{\prime}\right)$, indicating the presence of trans-di-substituted ethylene moiety in the molecule. The main spectroscopic data are resumed in Table 2.

Ky et al. (1997) compared different isolation methods on coffee beans previously crushed and frozen in liquid nitrogen. After an aqueous methanol $70 \%$ (v/v) extraction at $4{ }^{\circ} \mathrm{C}$ overnight, different methods were tested, based either on the aqueous extract (after evaporation of methanol): a solvent extraction with organic solvents (Rakotomalala, 1992); or a filtration through a C18 cartridge (Bicchi et al., 1995); or a treatment by Carrez reagents (Balyaya and Clifford, 1995); or on the methanol extracts (without evaporation of methanol): Carrez reagents (Trugo and Macrae, 1984); or directly analyzed by HPLC (DIN10767, 1992). When using an aqueous methanol 70\% (v/v) extraction combined with the Rakotomalala (1992) isolation method, they obtained $4.1 \%(\mathrm{db})$ of total CGA. In our study, treatment T3 (Table 2) is similar to that used by these authors and very close results were obtained $(5.87 \pm 1.1 \% \mathrm{db}$ of total CGA).
Table 1

Green coffee chlorogenic acids extraction and isolation yields.

\begin{tabular}{lll}
\hline Treatment $(\mathrm{T})$ & Extraction/isolation method & $\begin{array}{l}\text { Total CGA } \\
\left(\% \mathrm{db}^{\mathrm{b}}\right)\end{array}$ \\
\hline T1 & Water $80^{\circ} \mathrm{C} /$ Rakotomalala (1992) & $5.62 \pm 0.8^{\mathrm{c}}$ \\
T2 & Water $80^{\circ} \mathrm{C} /$ activated carbon & $5.07 \pm 1.0$ \\
T3 & Methanol 70\% (v/v)/Rakotomalala (1992) & $5.87 \pm 1.1$ \\
T4 & Methanol 70\% (v/v)/activated carbon & $4.67 \pm 1.6$ \\
T5 & Isopropanol 60\% (v/v)/Rakotomalala (1992) & $5.87 \pm 1.0$ \\
T6 & Isopropanol 60\% (v/v)/activated carbon & $5.28 \pm 1.2$ \\
\hline
\end{tabular}

a Chlorogenic acids.

b Dry basis.

c Mean of triplicates (mean values \pm standard deviations).

Table 2

${ }^{13} \mathrm{C}$ NMR and ${ }^{1} \mathrm{H}$ NMR $(500 \mathrm{MHz}$, methanol-D 4 ) chemical shifts for 5-O-caffeoyl quinic acid.

\begin{tabular}{lll}
\hline $5-\mathrm{CQA}^{\mathrm{a}}$ number of carbon (Fig. 1) & ${ }^{13} \mathrm{C}(\delta / \mathrm{ppm})$ & ${ }^{1} \mathrm{H}(\delta / \mathrm{ppm})$ \\
\hline 1 & 74.71 & $2.02 \mathrm{br} \mathrm{t}^{\mathrm{b}}$ \\
2 & 37.33 & $2.22 \mathrm{br} \mathrm{d}^{\mathrm{b}}$ \\
3 & & $5.31 \mathrm{t}^{\mathrm{b}}$ \\
4 & 70.51 & $3.71 \mathrm{~d}^{\mathrm{b}}$ \\
5 & 72.06 & $4.15 \mathrm{br} \mathrm{s}^{\mathrm{b}}$ \\
6 & 70.57 & $2.05 \mathrm{br} \mathrm{d}$ \\
& 36.76 & $2.14 \mathrm{~d}$ \\
7 & & \\
$1^{\prime}$ & 175.61 & $7.027 \mathrm{br} \mathrm{s}$ \\
$2^{\prime}$ & 126.36 & \\
$3^{\prime}$ & 113.86 & $6.94 \mathrm{~d}$ \\
$4^{\prime}$ & 145.33 & $6.75 \mathrm{~d}$ \\
$5^{\prime}$ & 148.11 & $7.56 \mathrm{~d}$ \\
$6^{\prime}$ & 115.07 & $6.22 \mathrm{~d}$ \\
$7^{\prime}$ & 121.58 & \\
$8^{\prime}$ & 145.66 & \\
$9^{\prime}$ & 113.79 & \\
\hline a & 167.27 & \\
b $^{\prime}$ br $t$ broad triplet, $b r d$ broad doublet, $t$ triplet, $d$ doublet, $b r$ s broad singlet. & &
\end{tabular}

Results are consistent with the CGA coffee content reported in the literature (Clifford and Jarvis, 1988; Ky et al., 1997). Differences in results can be explained by the small variations between methods and by the coffee variety.

The use of water at $80^{\circ} \mathrm{C}$ combined with $\mathrm{AC}$ (treatment $\mathrm{T} 2$ in Table 2) is less polluting than treatments $\mathrm{T} 1$ and $\mathrm{T} 3$ to $\mathrm{T} 6$, gave a good extraction yield $(5.07 \pm 1.0 \% \mathrm{db})$, and presented no significant differences to alcohol extraction methods combined with AC.

\section{Conclusion}

In conclusion, the use of AC to isolate CGA presented no significant differences with the Rakotomalala (1992) method. Adsorption with AC proved to be a suitable means to trap CGA from a complex medium like a green coffee extract obtained either by alcohol of by hot water extraction. Adsorption of CGA on AC avoids the use of toxic solvents and is a simple and less timeconsuming method, and could be used to replace methods using solvents. This method is a good alternative prior to the purification of 5-CQA or another single (monomer or dimer) CGA, which are not always commercially available, or are very expensive.

\section{Acknowledgments}

We thank Dr. Jorge Suárez Medellín from the University of Veracruz (Mexico) for his analytical advices. Angelina Alonso Campos thanks CONACYT for her Master degree scholarship. 


\section{References}

Andrade, P.B., Leitao, R., Seabra, R.M., Oliveira, M.B., Ferreira, M.A., 1997. Development of an HPLC/diode-array detector method for simultaneous determination of seven hydroxycinnamic acids in green coffee. Journal of Liquid Chromatography and Related Technologies 20 (13) 2023-2030.

Balyaya, K.J., Clifford, M.N., 1995. Individual chlorogenic acids and caffeine contents in commercial grades of wet and dry processed Indian green Robusta coffee. Journal of Food Science and Technology-Mysore 32 (2) 104-108.

Bhatt, B., 2011. Chemical constituents of Solanum xanthocarpum. Journal of Chemical and Pharmaceutical Research 3 (3) 176-181.

Bicchi, C.P., Binello, A.E., Pellegrino, G.M., Vanni, A.C., 1995. Characterization of green and roasted coffees through the chlorogenic acid fraction by HPLC-UV and principal component analysis. Journal of Agricultural and Food Chemistry 43 (6) 1549-1555.

Budryn, G., Nebesny, E., Podsędek, A., Żyżelewicz, D., Materska, M., Jankowski, S., Janda, B., 2009. Effect of different extraction methods on the recovery of chlorogenic acids, caffeine and Maillard reaction products in coffee beans. European Food Research and Technology 228 (6) 913-922.

Clifford, M.N., 1999. Chlorogenic acids and other cinnamates - nature, occurrence and dietary burden. Journal of the Science of Food and Agriculture 79 (3) 362372.

Clifford, M.N., Jarvis, T., 1988. The chlorogenic acids content of green robusta coffee beans as a possible index of geographic origin. Food Chemistry 29 (4) 291-298.

Clifford, M.N., Johnston, K.L., Knight, S., Kuhnert, N., 2003. Hierarchical scheme for LC-MSn identification of chlorogenic acids. Journal of Agricultural and Food Chemistry 51 (10) 2900-2911.

Colonna, J.P., 1979. L'acide chlorogenique et les depsides de divers cafeiers africains et malgaches: leur participation au metabolisme et leur signification biologique. O.R.S.T.O.M., Paris, France.

Couteau, D., Mathaly, P., 1997. Purification of ferulic acid by adsorption after enzymic release from a sugar-beet pulp extract. Industrial Crops and Products 6, 237-252.

Creppy, E.E., 2002. Update of survey, regulation and toxic effects of mycotoxins in Europe. Toxicology Letters 127 (1-3) 19-28.

Debry, G., 1993. Le café et la santé.

Dibert, K., Cros, E., Andrieu, J., 1989. Solvent extraction of oil and chlorogenic acid from green coffee. Part I. Equilibrium data. Journal of Food Engineering 10 (1) $1-11$.

DIN-10767, 1992. Analysis of coffee and coffee products - determination of chlorogenic acids content - HPLC method..

Hernandez, C.E., Chen, H.H., Chang, C.I., Huang, T.C., 2009. Direct lipase-catalyzed lipophilization of chlorogenic acid from coffee pulp in supercritical carbon dioxide. Industrial Crops and Products 30 (3) 359-365.

IUPAC, 1976. Nomenclature of cyclitols. Biochemical Journal 153, 23-31.

Kammerer, D.R., Saleh, Z.S., Carle, R., Stanley, R.A., 2007. Adsorptive recovery of phenolic compounds from apple juice. European Food Research and Technology 224 (5) 605-613.

Kubo, I., Fujita, K., Nihei, K., 2002. Anti-Salmonella activity of alkyl gallates. Journal of Agricultural and Food Chemistry 50 (23) 6692-6696.

Ky, C.-L., Noirot, M., Hamon, S., 1997. Comparison of five purification methods for chlorogenic acids in green coffee beans (Coffea sp.). Journal of Agricultural and Food Chemistry 45 (3) 786-790.
Lewis, C.E., Walker, J.R.L., Lancaster, J.E., Sutton, K.H., 1998. Determination of anthocyanins, flavonoids and phenolic acids in potatoes. I: Coloured cultivars of Solanum tuberosum L. Journal of the Science of Food and Agriculture 77 (1) 45-57.

Lu, H.-T., Jiang, Y., Chen, F., 2004. Application of preparative high-speed countercurrent chromatography for separation of chlorogenic acid from Flos lonicerae. Journal of Chromatography A 1026 (1-2) 185-190.

Morishita, H., Iwahashi, H., Osaka, N., Kido, R., 1984. Chromatographic separation and identification of naturally occurring chlorogenic acids by $1 \mathrm{H}$ nuclear magnetic resonance spectroscopy and mass spectrometry. Journal of Chromatography A 315 (0) 253-260.

Morishita, H., Ohnishi, M., 2001. Absorption, metabolism and biological activities of chlorogenic acids and related compounds. In: Atta ur, R. (Ed.), Stud. Nat. Prod. Chem. Elsevier, pp. 919-953.

Murthy, P.S., Madhava Naidu, M., 2012. Sustainable management of coffee industry by-products and value addition-a review. Resources, Conservation and Recycling 66 (0) 45-58.

Olsson, L., Samuelson, O., 1974. Chromatography of aromatic acids and aldehydes and phenols on cross-linked polyvinylpyrrolidone. Journal of Chromatography A 93 (1) 189-199.

Rakotomalala, J.J.R., 1992. Diversité biochimique des caféiers: analyse des acides hydroxycinnamiques, bases puriques et diterpènes glycosides. Particularités des caféiers sauvages de la région malgache (Mascarocoffea chev.) Université Sciences et Techniques du Languedoc, Montpellier II, France, Montpellier, France, pp. 219.

Schieber, A., Hilt, P., Streker, P., Endreß, H.-U., Rentschler, C., Carle, R., 2003. A new process for the combined recovery of pectin and phenolic compounds from apple pomace. Innovative Food Science and Emerging Technologies 4 (1) 99107.

Scholz, E., Heinrich, M., Hunkler, D., 1994. Caffeoylquinic acids and some biologicalactivities of Pluchea-Symphytifolia. Planta Medica 60 (4) 360-364.

Soto, M.L., Moure, A., Dominguez, H., Parajo, J.C., 2011. Recovery, concentration and purification of phenolic compounds by adsorption: a review. Journal of Food Engineering 105 (1) 1-27.

Suárez-Quiroz, M.L., Alonso Campos, A., Valerio Alfaro, G., González-Ríos, O. Villeneuve, P., Figueroa-Espinoza, M.C., 2013a. Anti-Aspergillus activity of green coffee 5-O-caffeoyl quinic acid and its alkyl esters. Microbial Pathogenesis 61$62,51-56$.

Suárez-Quiroz, M.L., González-Ríos, O., Barel, M., Guyot, B., Schorr-Galindo, S. Guiraud, J.P., 2004. Effect of chemical and environmental factors on Aspergillus ochraceus growth and toxigenesis in green coffee. Food Microbiology 21 (6) 629-634.

Suárez-Quiroz, M.L., Taillefer, W., López Méndez, E.M., González-Ríos, O., Villeneuve, P., Figueroa-Espinoza, M.C., 2013b. Antibacterial activity and antifungal and anti-mycotoxigenic activities against Aspergillus flavus and A. ochraceus of green coffee chlorogenic acids and dodecyl chlorogenates. Journal of Food Safety 33 (3) 360-368.

Trugo, L.C., Macrae, R., 1984. Chlorogenic acid composition of instant coffees. Analyst 109, 263-266.

Yuan, B., Qiao, M., Xu, H., Wang, L., Li, F., 2006. Determination of chlorogenic acid in rat plasma by high performance chromatography after peritoneal administration of compound Daqingye injection. Yakugaku Zasshi Journal of the Pharmaceutical Society of Japan 126 (9) 811-814. 